\title{
Expression of CCL27 in Middle Ear Cholesteatoma
}

\author{
Yan Edward ${ }^{1 *}$ (D) Eva Decroli ${ }^{1}$, Hirowati Ali ${ }^{1}$ (D), Djong Hon Tjong ${ }^{2}$ (D) \\ ${ }^{1}$ Department of Otorhinolaryngology, Faculty of Medicine, Andalas University, Padang, Indonesia; ${ }^{2}$ Department of \\ Otorhinolaryngology, Faculty of Mathematics and Natural Sciences, Andalas University, Padang, Indonesia
}

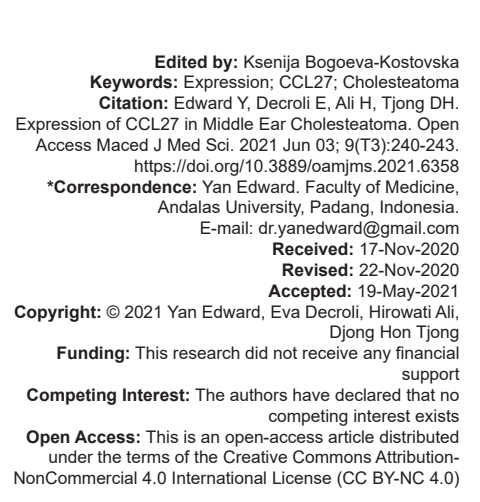

Introduction

Chronic suppurative otitis media (CSOM) is a chronic middle ear infection characterized by a history of continuous ear discharge from the middle ear through the perforated tympanic membrane [1], [2], [3]. Secretions in OMSK either disappear or occur continuously for more than 2 months [4]. The prevalence of CSOM in the world is 65-330 million people, especially in developing countries. The prevalence of CSOM in Indonesia, according to the national survey of sight and hearing health in 1994-1996, ranges from 3 to $5.2 \%$ [1], [4].

Cholesteatoma is a lesion of the temporal bone lined by stratified squamous epithelium that contains desquamated keratin. Cholesteatoma is considered more aggressive during childhood. The molecular mechanism of the pathogenesis of cholesteatoma formation is still unclear [5], [6], [7]. The incidence of cholesteatoma ranges from 9 to 12.6 cases per 100,000 adults and 3 to 15 cases per 100,000 children with male versus female 1.4: 1 [8].

The etiopathogenesis of cholesteatoma cannot be explained with certainty. The mechanisms underlying cholesteatoma etiopathogenesis are still under study. Four dominant theories are still under debate, namely invagination theory, migration, squamous metaplasia, and basal cell hyperplasia. However, there is no single theory that explains the clinical characteristics of cholesteatoma [9], [10], [11].

Biomolecular-level etiopathogenesis research has developed in understanding pathological mechanisms that form the basis for further research [8], [11]. Various studies have reported on the biology of cholesteatoma, but many questions remain unanswered. Cholesteatoma is hyperproliferative but does not show typical symptoms of neoplasia in the absence of metastases and the absence of genetic instability [6], [12].

The mechanisms for the destruction of the temporal bone by cholesteatoma are complex and still not fully understood. Bone destruction by cholesteatoma is caused by several factors, namely mechanical, biochemical, and cellular.

CCL27 is also known as a cutaneous $\mathrm{T}$ cell attracting chemokine (CTACK), which will accelerate skin regeneration. CCL27 is a keratinocyte-specific cytokine that mediates lymphocytes to skin sites through the CCR10-specific surface receptor. CCL27 plays an important role in $\mathrm{T}$ cell-mediated skin inflammation. CCL27 is a cytokine that belongs to the CC chemokine family, also known as IL-11 R-alpha-locus chemokine (ILC), Skinkine, ESkine, and CTACK. CCL27 is expressed in various tissues, including gonads, thymus, placenta, and skin [13]. 
In skin tumors derived from keratinocytes, there is a protective mechanism of antitumor T cellmediated by reducing CCL27 expression.

Keratinocytes in skin tumors avoid the $\mathrm{T}$ cell-mediated antitumor immune response by downregulation of CCL27 expression by activating the epidermal growth factor receptor (EGFR) -Ras-MAPK signaling pathway. The expression of $\mathrm{mRNA}$ and CCL27 protein is increasingly lost in altered keratinocytes such as actinic keratoses, basal, and squamous cell carcinomas when compared to healthy skin [13].

In Macias's study, there was also a decrease in CCL27 in cholesteatoma. The CCL27 expression level was 0.022 times in cholesteatoma compared to PAS with microarray examination and 0.019 with qRTpolymerase chain reaction (PCR). Anti-CCL27 staining with IHK illustrates strong protein reactivity in all layers, especially in the superficial layer and endothelial cells PAS [14].

This study was conducted to analyze the CCL27 gene expression in cholesteatoma patients with CSOM.

\section{Methods}

The subjects of this study were the biological material (cholesteatoma as case and retroauricular skin as control) of CSOM patients who had undergone tympanomastoidectomy in Dr. M. Djamil Hospital Padang. A total of 15 cases of cholesteatoma as case and retroauricular skin as a control included in the study. The study was approved by the ethics committee of the Faculty of Medicine, Andalas University, Padang, Indonesia (No.353/KEP/FK/2020).

Cholesteatoma samples were taken from the mastoid cavity, while normal ear skin was taken from retroauricular skin with a size of $0.5 \mathrm{~cm}$ when tympanomastoidectomy was performed in the operating room. Cholesteatoma collection is included in one of the steps of the tympanomastoidectomy procedure where the sample material was taken the residual material of the operation that will be examined for Anatomical Pathology at the Anatomical Pathology Laboratory. Part of the cholesterol was taken and sampled, put into a microtube containing $0.5 \mathrm{ml}$ of RNA letters, then stored at $-80^{\circ} \mathrm{C}$ in the Biomedical Laboratory of the Faculty of Medicine, Andalas University, Padang.

Primers for recognizing the CCL27 gene have been previously described and reconfirmed. Primers used for CCL27 amplification are forward: 5AGCAGCCTCCCGCTGTTACTGTTG-3 and reverse: 5-TGCTTTATTAGTTTTGCTGTTGGG-3.

Gene expression analysis using real-time PCR (RT-PCR) with two approaches is relative quantification and absolute quantification. In this study, the analysis of CCL27 expressions in absolute quantification and comparative CT method $(\Delta \Delta \mathrm{Ct})$ was carried out.

\section{Results}

A total of 15 patients were included in this study and all the information was compiled and presented in the form of tables. Samples characteristic can be seen in Table 1

Table 1: Distribution of patients by gender $(n=15)$

\begin{tabular}{lll}
\hline Gender & f & $(\%)$ \\
\hline Male & 8 & 53.3 \\
Female & 7 & 46.7 \\
\hline
\end{tabular}

Table 1 shows that male is more affected $(53.3 \%)$ than female $(46.7 \%)$. The ratio of male and female is 1.14: 1 . The average age of this study is 22.7 \pm 9.7 years old.

Table 2 shows that almost all the patients presented with more than one symptom. The most common symptoms were discharge from the ear $(100 \%)$ and hearing impairment $(100 \%)$ followed by postauricular swelling $(33.3 \%)$ and headache $(26.7 \%)$. A few patients complained vertigo $(6.7 \%)$ and facial paralysis $(6.7 \%)$. Table 2 also shows some of the patients who suffered from those clinical presentations for $11-15$ years $(33.3 \%)$

Table 2: Distribution of patients by symptoms and its duration ( $n=15)$

\begin{tabular}{lll}
\hline Characteristic & $\mathrm{f}$ & $\%$ \\
\hline Symptom & & \\
Discharge from ear & 15 & 100 \\
Hearing impairment & 15 & 100 \\
Vertigo & 1 & 6.7 \\
Facial paralysis & 1 & 6.7 \\
Retroauricular swelling & 5 & 33.3 \\
Headache & 4 & 26.7 \\
Seizure & 0 & 0 \\
Decrease of consciousness & 0 & 0 \\
Symptom duration (year) & & \\
$<5$ & 3 & 20 \\
$6-10$ & 2 & 13.3 \\
$11-15$ & 5 & 33.3 \\
$16-20$ & 3 & 20 \\
$21-25$ & 1 & 6.7 \\
$26-30$ & 1 & 6.7 \\
\hline
\end{tabular}

Table 3 shows most of the patients in this study have total tympanic membrane perforation $(66.6 \%)$ followed by attic perforation (26.7\%) and subtotal perforation $(6.7 \%)$.

Table 3: Distribution of patients by tympanic membrane perforation type $(n=15)$

\begin{tabular}{lll}
\hline Tympanic membrane perforation type & $\mathrm{f}$ & $\%$ \\
\hline Attic & 4 & 26.7 \\
Subtotal & 1 & 6.7 \\
Total & 10 & 66.6 \\
\hline
\end{tabular}

The mean CCL27 gene expression between the cholesteatoma group and the retroauricular group can be seen in Table 4. 
Table 4: Mean CCL27 gene expression in cholesteatoma group and retroauricular skin

\begin{tabular}{llll}
\hline Group & $\mathrm{f}$ & $\begin{array}{l}\text { Expression of CCL27 } \\
\text { Mean } \pm \text { SD }\end{array}$ & $\mathrm{p}$ \\
\hline Cholesteatoma & 15 & $36.215 \pm 45.848$ & 0.118 \\
Retroauricular skin & 15 & $9.692 \pm 15.790$ & \\
\hline
\end{tabular}

The mean CCL27 gene expression in the cholesteatoma group was $286.603 \pm 506.001$, where the mean was higher than the mean of the retro auricular skin group, $7.446 \pm 20.496$. CCL27 gene expression increased but not significantly compared to the retroauricular skin group ( $p>0.05)$

\section{Discussion}

CCL27 is a cytokine that belongs to the CC chemokine family which is also known as IL-11 R- alpha-locus chemokine (ILC), Skinkine, ESkine, and CTACK. CCL27 is expressed in various tissues, including gonads, thymus, placenta, and skin [15]. CCL27 plays a role in skin inflammation mediated by $\mathrm{T}$. Louw cells, which was cited by Wei [15] investigating the pathogenesis of cholesteatoma and found evidence that chronic inflammation is the initiator of cholesteatoma formation, growth, and expansion. Cholesteatoma formation involves the release of many cytokines and mediators in the inflammatory process. The cytokines secreted in the inflammatory response may alter the biochemical signaling pathway of the hyperproliferative keratinocytes of cholesteatoma. CCL27 is a chemokine that plays a role in the process of cell proliferation in cholesteatoma [15].

In this study, using RT-PCR, the expression of the CCL27 gene in cholesteatoma increased compared to retroauricular skin, with a mean of $36.215 \pm 45.848$ and $9.692 \pm 15.790$ but statistically, there was no significant difference $(p=0.118)$. This result was different in Marcia's study [14]; there was a decrease in CCL27 gene expression in cholesteatoma compared to retro skin auricles by 0.019 times with real-time PCR. Marcias suspects that the decreased expression of the CCL27 gene is due to the behavior of cholesteatoma that resembles carcinoma, such as squamous cell carcinoma. In squamous cell carcinoma, there is an activation of the EGFR-Ras-MAPK pathway resulting in decreased expression of the CCL27 gene. In skin tumors derived from keratinocytes, there is a protective mechanism of antitumor T cell-mediated by reducing the expression of the CCL27 gene [13]. Zang and Li [16], who examined the $\mathrm{CPI}$, showed a decrease in CCL27 expression in cholesteatoma compared to normal ear skin, $6.7 \%$ and $33.3 \%$.

Various cytokines play a role in the regulation of CCL27. According to Kurokawa's hypothesis [17], there are several pathways for the regulation of CCL27 expression, namely through TNF alpha and gamma IFN. TNF alpha induces CCL27 through the ERK, p38, JNK, and NFKB pathways. TNF alpha also activates STAT3, which suppresses CCL27. TNF alpha works in the initial phase, while gamma IFN suppresses alpha TNF through the STAT1/STAT3, EGFR, and ERK pathways so that it suppresses CCL27. It is suspected that gamma IFN works in an advanced phase [18]. Kurakawa et al. [17], citing from Vestergarg et al., also found the same thing about CCL27 regulation.

In this study, there was a tendency to increase the expression of the CCL27 gene; this may be the role of the TNF alpha pathway through ERK, p38, JNK, and NFKB [17]. In our previous study, there was an increase in the expression of the TNF alpha gene in cholesteatoma compared to retro skin auricles [19]. Maniu [6] also obtained the same results where there was an increase in TNF alpha gene expression, while the pathway that suppresses CCL27 by TNF alpha and gamma IFN through EGFR, ERK, and STAT3 has not. Therefore, it is necessary to conduct further research on whether the gamma IFN pathway, EGFR plays a role in the CCL27 regulation.

EGFR is also associated with the suppression of CCL27, a keratinocyte-specific chemokine that plays an important role in regulating immune response in the skin by regulating T-cell homing (cellular migration process) under homeostatic and inflammatory conditions [13]. EGFR tyrosine kinase inhibitor will increase CCL27 expression. Meanwhile, EGFR and Ras activation will suppress CCL27 expression in keratinocytes. Skin cancer patients treated with the EGFR inhibitor, Erlotinib, showed increased CCL27 protein in the epidermis, providing in vivo evidence that CCL27 expression was regulated by EGFR signals [13].

\section{Conclusion}

Our study reveals that expression of the CCL27 gene was increased in cholesteatoma compared to controls, but it was not statistically significant.

\section{References}

1. World Health Organization. Chronic Suppurative Otitis Media Burden of Illness and Management Options, WHO Library. Geneva: World Health Organization; 2004.

2. Utami TF, Sudarman K, Udji B, Rianto D, Christanto A. Allergic Rhinitis as a Risk Factor of Chronic Suppurative Otitis Media. Cermin Dunia Kedokt. 2010;179:425-9.

3. Darmawan AB, Anjarwati DU. The Sensitivity Difference of Eardrop Antibiotic against Pseudomonas aeruginosa in chronic suppurative otitis media. Oto Rhino Laryngol. Indones. 
2012;42(2):77-82. https://doi.org/10.32637/orli.v42i2.22

4. Helmi H. Otitis media supuratif kronis. In: Otitis Media Supuratif Kronis Pengetahuan Dasar Terapi Medik Mastoidektomi Timpanoplasti. Jakarta: Balai Penerbit FKUI; 2005. https://doi. org/10.32637/orli.v49i20.302

5. Likus W, Siemianowicz K, Markowski J, Wiaderkiewicz J, Kostrząb-Zdebel A, Jura-Szołtys $\mathrm{E}$, et al. Bacterial infections and osteoclastogenesis regulators in men and women with cholesteatoma. Arch Immunol Ther Exp (Warsz). 2016;64(3):241-7. https://doi.org/10.1007/s00005-015-0373-7 PMid:26584851

6. Maniu $A$, Harabagiu $O$, Schrepler MP, Cătană $A$, Fănuţă $B$, Mogoantă CA. Molecular biology of cholesteatoma. Rom J Morphol Embryol. 2014;55(1):7-13.

PMid:24715159

7. Mayer TA, Strunk CL, Lampert PR. Cholesteatoma. In: Johnson J, Rosen C, editors. Head and Neck Surgery Otolaryngology. Philadelphia, PA: Lippincot William \& Wilkins; 2014.

8. Kuo CL. Etiopathogenesis of acquired cholesteatoma: Prominent theories and recent advances in biomolecular research. Laryngoscope. 2015;125(1):234-40. https://doi. org/10.1002/lary.24890

PMid:25123251

9. Jackler RK, Santa Maria PL, Varsak YK, Nguyen A, Blevins NH. A new theory on the pathogenesis of acquired cholesteatoma: Mucosal traction. Laryngoscope. 2015;125 Suppl 4:S1-14. https://doi.org/10.1002/lary.25261

PMid:26013635

10. Kuo CL, Shiao AS, Yung M, Sakagami M, Sudhoff $\mathrm{H}$, Wang $\mathrm{CH}$, et al. Updates and knowledge gaps in cholesteatoma research. Biomed Res Int. 2015;2015:854024. https://doi. org/10.1155/2015/854024

PMid:25866816

11. Hamed MA, Nakata S, Sayed RH, Ueda H, Badawy BS, Nishimura $Y$, et al. Pathogenesis and bone resorption in acquired cholesteatoma: Current knowledge and future prospectives. Clin Exp Otorhinolaryngol. 2016;9(4):298-308. https://doi. org/10.21053/ceo.2015.01662

PMid:27440129

12. Kanemaru SI, Kikkawa $\mathrm{Y}$, Omori $\mathrm{K}$, Ito J. Bone destructive mechanisms of cholesteatoma. Laryngoscope. 2010;120(S3):S79. https://doi.org/10.1002/lary.21268

13. Pivarcsi A, Müller A, Hippe A, Rieker J, van Lierop A, Steinhoff $M$, et al. Tumor immune escape by the loss of homeostatic chemokine expression. Proc Natl Acad Sci USA. 2007;104(48):19055-60.

PMid: 18025475

14. Macias JD, Gerkin RD, Locke D, Macias MP. Differential gene expression in cholesteatoma by DNA chip analysis. Laryngoscope. 2013;123 Suppl S5:S1-21. https://doi. org/10.1002/lary.24176

PMid:23670528

15. Liu W, Yin T, Ren J, Li L, Xiao Z, Chen X, et al. Activation of the EGFR/Akt/NF- KB/cyclinD1 survival signaling pathway in human cholesteatoma epithelium. Eur Arch Otorhinolaryngol. 2014;27(2):1265-73. https://doi.org/10.1007/s00405-013-2403-6 PMid:23463347

16. Menglu Z, Yongtuan LI. Expression of chemokine ligand 27 in secondary middle ear. J Shandong Univ. 2017;31(6):46-8.

17. Karakawa M, Komine M, Hanakawa $Y$, Tsuda H, Sayama $K$, Tamaki K, et al. CCL27 is downregulated by interferon gamma via epidermal growth factor receptor in normal human epidermal keratinocytes. J Cell Physiol. 2014;229(12):1935-45. https://doi. org/10.1002/jcp.24643 PMid:24710735

18. Gazel A, Nijhawan RI, Walsh R, Blumenberg M. Transcriptional profiling defines the roles of ERK and p38 kinases in epidermal keratinocytes. J Cell Physiol. 2008;215(2):292-308. https://doi. org/10.1002/jcp.21394

PMid: 18247374

19. Edward Y, Munilson J, Rosalinda R, Ali H, Irfandy D, Swanda D. Expression of tumor necrosis factor-a and interleukin-6 in chronic suppurative otitis media. Turk J Immunol. 2019;7(1):1-5. https://doi.org/10.25002/tji.2019.782 